\title{
Central Planning in the Netherlands
}

\section{J. Tinbergen}

The Review of Economic Studies, Vol. 15, No. 2. (1947 - 1948), pp. 70-77.

Stable URL:

http://links.jstor.org/sici?sici=0034-6527\%281947\%2F1948\%2915\%3A2\%3C70\%3ACPITN\%3E2.0.CO\%3B2-Q

The Review of Economic Studies is currently published by The Review of Economic Studies Ltd..

Your use of the JSTOR archive indicates your acceptance of JSTOR's Terms and Conditions of Use, available at

http://www.jstor.org/about/terms.html. JSTOR's Terms and Conditions of Use provides, in part, that unless you have obtained prior permission, you may not download an entire issue of a journal or multiple copies of articles, and you may use content in the JSTOR archive only for your personal, non-commercial use.

Please contact the publisher regarding any further use of this work. Publisher contact information may be obtained at http://www.jstor.org/journals/resl.html.

Each copy of any part of a JSTOR transmission must contain the same copyright notice that appears on the screen or printed page of such transmission.

JSTOR is an independent not-for-profit organization dedicated to and preserving a digital archive of scholarly journals. For more information regarding JSTOR, please contact support@jstor.org. 


\section{Central Planning in the Netherlands}

\section{GENERAL OBJECTS OF PLANNING}

Immediately after the Liberation the Netherlands were faced with a severe shortage of all essential goods, particularly in the Western part of the country, where the period of famine had led to a complete exhaustion of all stocks, and where the Germans had deliberately destroyed the railway system. At that time there was no alternative to a policy of rigorous planning, approaching that of a war economy. After the worst damage had been repaired and the shortages partially alleviated, it became apparent that the pent-up demand (backed by abundant liquid reserves), was so much larger than production and imports together, that an allocation and rationing system would be necessary to prevent inflation. It was not a matter of principle, but the compelling nature of the circumstances which led to the continuation of a policy of detailed planning. Even now the situation in the Netherlands, as compared with that of the other North-Western European countries, makes rigorous planning more necessary than elsewhere. The combined effect of $(a)$ war damage, $(b)$ the loss of income from overseas investments, $(c)$ the chaos in the German hinterland, and $(d)$ the large increase in population, is affecting the Netherlands more seriously than any other North-Western European country.

The primary object of this planning is to restore equilibrium between :

(a) Imports and exports ;

(b) Supply of consumers' goods and a tolerable standard of living for the mass of the population;

(c) New investment; and

(d) The increase in population.

In the more remote future it is probable that the economic policy of the Netherlands will gradually tend towards an employment policy which will use more indirect methods of influencing production, consumption and prices.

It is the intention of this paper to give a short account of the chief features of the present system of drawing-up the nation's economic budget. This will be dealt with under the following heads:

Section 2-The Range of Planning.

Section 3-The Machinery of Planning.

Section 4-Principles on which Planning is Based.

Section 5-General Direction of C.P.B. Policy.

\section{THE RANGE OF PLANNING}

In this section there will be given a short outline of planning in the Netherlands ; on account of its brevity it cannot be detailed. It should also be kept in mind that the measures adopted are subject to continual change. A distinction will be made in what follows between planning with respect to quantities and to prices.

\section{The Planning of Quantities}

The economic activity of any country may be roughly described as a complex system of mainly parallel flows of goods and services, partly inter-connected and intertwined, passing from primary producers to ultimate consumers. For a country with international trade, imports should be reckoned under primary production, and exports as a form of ultimate consumption. Consumption is to be understood in a 
sense wider than the usual one, as including the buying of finished investment goods. By comparing the origin and the destination of these flows we may state that:

imports + production $=$ exports + private consumption + private investment + government expenditure.

It will be useful to consider separately the various items expressed in this equation.

\section{(a) Imports}

All imports are subject to import licences. The framework of this licensing system is supplied by :

(i) bilateral trade agreements with most European countries ;

(ii) import programmes relating to other areas among which the dollar area is the most important.

The distribution of imports among individual firms is the task of some ten to twenty industrial bureaux under the Ministry of Economic Affairs. Various principles are applied, but most frequently the allocations are based on the operations of each firm in a previous period. Sometimes it is possible to take into account the prices at which individual importers are able to buy and to give preference to the lowest. The productive capacity of the various firms is also taken into consideration ; the purpose being to utilise that capacity to the fullest extent.

\section{(b) Production}

The main stages of production may be distinguished as: production of raw materials (i) agriculture, (ii) mining; (iii) manufacturing industry, (iv) building, (v) trade, (vi) transport, (vii) housing, and (viii) other services; they will be considered briefly in turn.

(i) Agriculture. Production is in most cases no longer directly controlled, but is so indirectly by means of price fixing. In principle the full quantity produced (after deduction for personal consumption) has to be delivered to a series of semi-public bodies dealing with the separate products. Fertilisers and fodder are allocated.

(ii) Mining. Mining in the Netherlands is chiefly coal mining, and production is still below the desired level. Attempts to increase production have all been of an indirect type ; special provisions (utensils, clothing, etc.) for the miners, and propaganda, to encourage recruits to join the industry, have been the chief measures taken so far. Recently special attention has been given to housing conditions. A number of political delinquents are working in the mines if they prefer this to being in camps.

(iii) Manufacturing Industries. A licence is necessary for every plant employed in production. Most of the raw materials are obtained by allocation, particularly the imported ones. Coal is rationed by the State Coal Office. Labour is free but skilled labour is very scarce, and unskilled labour is scarce. For the allocation of raw materials, cf. under imports.

(iv) Building. A building permit is required for all construction except for a few categories of public works (those executed by the permanent personnel of public authorities, and then only so long as little material is required). Building permits are issued according to the building plan, which is drawn up once a year and shows the distribution of building activity according to categories and regions. The regional offices of the Ministry of Reconstruction allocate raw materials to the individual firms. If "black market" building activity is detected, the structure in question may be demolished.

(v) Trade. Trade in essential goods is regulated as a consequence of rationing and allocations in the productive sphere. In a number of cases the tickets and coupons from the consumers must be handed over by the retailer to the wholesaler, and on to the producer. Import and export trade are wholly subject to licence. Trade in a 
number of less essential commodities is free, however (cf. section on consumption). Gradually more and more goods are coming off the ration. Goods with no regular demand (e.g. business machines) are allocated by the trade itself.

(vi) Transport. Railway transport, in most cases a public or semi-public concern, is automatically under control, although this is not very strict. Road transport, i.e. the use of a car, is subject to permit, but petrol is unrationed. Driving on Sunday is not as a rule permitted.

(vii) Housing. A family of $n$ members is entitled to occupy $n+\mathrm{I}$ rooms. If more rooms are available in any dwelling, these may be allocated to other families by the local authorities.

(viii) Other services. As a rule other services are freely available except where specific regulations influence their supply (e.g. import of films is restricted).

\section{(c) Private Consumption}

Most essential consumers' goods are subject to rationing : bread, flour products, sugar, chocolate, meat, cheese, milk, butter, margarine, fats and vegetable oil, tea, coffee, cocoa, cigarettes, pipe tobacco, most textiles, coal, gas and electricity. Among the unrationed goods are potatoes, fish, vegetables, fruit, shoes, cigars and drinks, the last two in restricted supply.

It has been mentioned above that consumers' coupons and tickets have to be passed on to producers by retailers and wholesalers. In a small number of cases it has been technically possible to allocate supplies of raw materials to producers according to the number of tickets they supply. In most cases, however, the relation between consumers' goods and raw materials is considered to be insufficiently rigid to permit such a connection.

\section{(d) Investment}

(i) Building. As has been mentioned, building activity is very strictly regulated. Apart from physical restrictions, there are also financial controls, particularly for public authorities and in an indirect way for residential building as well. Rents are subject to approval and are generally fixed at such a low level that subsidisation by public authorities is necessary.

(ii) Metal Products. Imported finished investment goods are subject to review by a special committee which considers all important products individually. Payback time is one of the criteria by which these plans are judged. Attention is given in addition to projects which are considered to be important for the general industrial development of the country. Home-produced investment goods can be ordered freely, but delivery depends on the availability of the raw materials used in their production.

(iii) Raw Materials. Raw materials in general, and hence also those which are used for increasing working capital, are subject to import control (see above).

\section{(e) Exports}

Formally a permit is also required for exports, and sometimes this implies a price control. It is sometimes made obligatory to export following the allocation of raw materials, and this may apply either individually or collectively for a certain branch of industry. The proceeds of exports in foreign currency have to be handed over to the Central Bank, the exporter receiving the official guilder value.

\section{(f) Co-ordination of Controls}

In some cases several controls are applied to the same object (building, raw material allocation and production licences, etc.). Gradually these controls are now being co-ordinated. 


\section{PRICES}

(a) Prices by :

The prices of consumers' goods have been kept below the level of free competition

(i) Subsidies, amounting to about 4.5 per cent of the National Income ;

(ii) Direct price control by the director-general of prices.

In most cases prices must be in conformity with a co-ordinated scheme and sometimes individual prices are fixed. Not only rationed articles but almost all essential goods and services are subject to some price regulation. Rents are at the I940 level with a few exceptions; rents for new houses are at a somewhat higher rate.

\section{(b) Wages}

In order to prevent inflation there has been a wage-stop since October, I946, up to which time two wage increases had been sanctioned in view of the increase in the cost of living. Real wages are on the average between 90 and roo per cent of the pre-war rates ; agricultural wages have risen to I25 per cent ; skilled workers' wages are generally below 90 per cent of pre-war level. Increases are only legal when they are approved by the Board of State Arbiters, and employers paying illegal wages may be fined.

\section{(c) Interest Rates}

The government follows a cheap-money policy, based on a 3 per cent level for long-term State bonds. Some small concessions have recently been made for very long-term loans. The yield on house mortgages is fixed at 4 per cent.

\section{THE MACHINERY OF PLANNING}

Owing to the complicated nature of the planning machinery it was felt that a co-ordinating body was needed to give general direction to the programmes in particular sectors and for overall economic policy. This task has been allotted to the Central Planning Bureau (C.P.B.) by the Act ${ }^{1}$ establishing the Central Economic Plan of April 2Ist, I947.

The formal status of the Central Planning Bureau is that of an advisory committee to the Minister of Economic Affairs. (The Ministry of Reconstruction is wholly concerned with building). The members of the Bureau are appointed by the Government ; some are civil servants, some independent experts, the remainder represent employers' associations or trade unions. In addition to the Central Planning Bureau there is a committee of civil servants (mainly Permanent Secretaries) acting as a liaison between the Bureau and the Ministers concerned. It is their business to prepare the discussions by the Ministers of the Central Economic Plan.

The C.P.B. is organised in three divisions concerned respectively with :

(i) The master plan;

(ii) The detailed partial plans;

(iii) General questions.

1 The main points of the law of April 21st, I947, establishing the Central Planning Bureau are as follows :

(I) The Central Planning Bureau shall be located under the Minister of Economic Affairs.

(2) The Central Planning Bureau is charged with the preparation of a Central Economic Plan, to be drawn up periodically by the Government, in order to co-ordinate public policy in the economic, social and financial spheres.

(3) The Central Economic Plan shall be a consistent body of estimates and directives with respect to the whole Dutch economy.

(4) The Central Economic Plan shall include, i.e. figures relating to the future volume of production, the level and development of prices, the national income and its components, public and private expenditure, and other factors relevant to the co-ordination of economic, social and financial policy. 
Its personnel consists of some eighty persons, of whom about thirty-five form the scientific staff. Most of the latter are economists, but there are also engineers, lawyers, sociologists and members with business experience.

The law provides for the setting up of a number of committees to give directions to policy or to assist in other ways. Some of these committees may be of a mixed composition, numbering among their members officials and also representatives of business and workers; other committees are purely official.

A few examples may be given of the directives suggested by the C.P.B. Import plans, particularly those for I948, have been based on alternative macro-economic plans established by the C.P.B. when, owing to the uncertainty of the period preceding the enactment of the United States' Foreign Assistance Act, it was necessary to make alternative plans. Building, and investment plans in general, have so far been jointly formulated by the C.P.B. and the Ministry of Reconstruction. Various aspects of general financial policy have been based on C.P.B. estimates of national income, tax receipts and monetary development expected in the near future. Wage policy has been drawn up largely on the advice of the Bureau.

\section{PRINCIPLES ON WHICH PLANNING IS BASED}

\section{Planning in Respect of Quantities}

Generally speaking the methods used by the C.P.B. aim to combine the practical and the theoretical. Most programmes represent a compromise between two approaches, one starting from the macro-economic standpoint, the other setting out from the individual requirements of the various industries and public authorities. At first only "practical methods" were used, e.g. import programmes were based on quantitative estimates of the availability of raw materials, industrial capacity, demand and so on. Since the C.P.B. started work an attempt has been made to construct a framework within which future development can be directed to bring about an optimum distribution of resources.

As an example of the co-operation in planning now achieved, we may take the present method of preparing the export estimates. The C.P.B. for its part, draws up provisional estimates based on the one hand on the expected trends of the national incomes of the Netherlands' customer nations, on the other on econometric demand studies for the various goods concerned. These provisional estimates are then compared with estimates made by "insiders." If any serious discrepancies between the two sets of estimates are found, a detailed discussion is held concerning the bases of the respective figures. By this method it is usually possible to reach a series of agreed figures.

Take again the construction of output targets. For its part the C.P.B. draws up provisional estimates based on general statistical data and methods. Thus the volume of total output is estimated from the number of the working population and the expected trend of labour productivity ; the volume of exports is estimated according to the method just explained ; consumption is estimated from statistics of the demand structure of the Dutch economy. Finally the import programme is derived from the combination of the estimates for output, exports and consumption.

With the help of a large number of standards the programmes for the various industries are integrated in a series of tables, indicating among other things the targets for mutual deliveries. On the other side, the Ministry of Economic Affairs, through its offices, draws up detailed industrial programmes. These programmes are compared with the C.P.B.'s programmes, and the differences discussed. There is an increasing tendency for the Ministry to base its detailed programmes on certain of the macroeconomic factors estimated by the C.P.B. 
It will be seen from the foregoing that the method of the C.P.B. itself makes use of two approaches: one working from macro-economic concepts downwards to more detailed figures, the other starting with branch figures supplied by branch experts, and integrating them into overall plans. The second method provides, from the theoretical point of view, a necessary correction of the results of the macro-economic approach ; necessary because mistakes are unavoidable in any system of aggregating by means of index numbers or similar devices. Only through the second approach is it possible to allow for the many local bottlenecks and similar deviations from the consistent trend which is the implicit hypothesis of any macro-economic analysis.

In allocating the national resources to two or three broad categories such as government expenditure, consumption and investment, the C.P.B. cannot really make use of scientific concepts such as the maximisation of marginal utility. In the first place the preferences of individuals are (within wide limits) uncertain ; and, of course, the preferences of one individual may be contradictory to those of another. Secondly, the government has to keep in view the interests of the community as a whole, which may be neglected by the individual. Thirdly, many data are still lacking. Every effort is made, however, to use the most objective methods available, some of these have been described elsewhere. ${ }^{1}$

Initially the volume of public expenditure had to be taken as a datum. It was only at a later stage that proposals could be put forward for retrenchment in some directions, primarily those concerned with public works. In respect of investment the main consideration on which the programmes have been based was the necessity to create sufficient equipment to enable the working population of 1952 to be employed at full capacity. Given the rapid increase in population, it will be necessary to undertake considerable new investment for the additional workers. The programme for this has been based on existing average capital per worker in manufacturing industry in the Netherlands. This is admittedly a very rough measure indeed, and the Bureau is continually revising the estimates on the basis of the investment projects that have been proposed since the Liberation. In addition, separate estimates have now been made of the required development in the different industries. These estimates will make it possible to break down and check the calculations of total new investment.

In respect of consumption the accepted norm has been a return to pre-war food standards. Actually the standard of nutrition in the Netherlands is still below the pre-war level, and even further below what is considered satisfactory on medical grounds. For the time being, however, the immediate goal remains the restoration of the pre-war standard. In respect of other consumers' goods the estimates of the C.P.B. have been based on the assumption that the pre-war proportions between the amounts spent on the various consumers' goods should be restored. Since in I938 consumption was completely unrestricted, it is assumed that the pre-war layout of expenditure corresponded to the maximum satisfaction obtainable with the available resources. Adjustments were naturally made for changes in relative prices, changes in consumption habits, and last but not least for changes in the need for durable goods as a consequence of the war. With the statistical data at their disposal the Bureau has attempted to compute a consumption plan as nearly as possible along these lines. This plan has, of course, had to be adapted to current availabilities ; in particular, textiles, fats and meat were, and are still, in such short supply that it has not been possible to allocate them at all closely in line with the pre-war distribution of expenditure.

1 J. Tinbergen: "Problems of Central Economic Planning in the Netherlands," Nationalokonomisk Tidsskrift, 1947, p. 96, and J. Tinbergen: "The Netherlands' Central Economic Plan for 1947," Schweitzerische Zeitschrift fur Volkswirtschaft und Statistik, 1947, p. 19. 
A word should perhaps be added concerning the procedure for implementing the Central Economic Plan. The 1947 plan was sent to the Parliament in September, I946, and discussed by the members, but neither accepted nor rejected. The plan was couched in the form of an advisory memorandum from the C.P.B. to the Government, " within the broad lines of accepted Government policy," as the preface stated. It was published as an annexe to the Budget. The I948 plan has been introduced in sections, for the most part in documents relating to the Balance of Payments situation, which have been presented to the Parliament by the Minister of Finance. It will be clear from this experience that the Government is still undecided on their procedure and is still looking for the best method.

\section{PRICE PolICY}

As we have seen, the starting-point of price-policy in the Netherlands was the desire to bring money wages to a level which would enable the Netherlands to compete in world markets. The determination of this level was based primarily on a comparison with Great Britain. Taking into account the depreciation of the guilder after the end of the war, and the (estimated) difference in labour productivity in the two countries, a " competitive" wage level was calculated. It appeared that the actual wage level in 1946 was already somewhat higher than this ; but since October, I946, the wage-stop in the Netherlands has made it possible to reduce the margin between Dutch and English wages. Recently an investigation made by the Netherlands' Economic Institute ${ }^{1}$ suggests that average labour cost per worker in manufacturing industry, expressed as a percentage of the pre-war figure, is now the same for the United States, the United Kingdom and the Netherlands. In view of the serious dislocation in both the British and the Dutch balances of payments it seems reasonable to propose as a further target a wage-level which is at least ro per cent below the corresponding American level. Holland, like Britain, has to substitute exports for income from former foreign investments; and this seems to be a legitimate reason for fixing the wage-level relatively lower in respect of America than was the case before the war.

\section{GENERAL DIRECTION OF C.P.B. POLICY}

As we have seen above, the Netherlands are in a relatively difficult position because of the accumulated effects of heavy war damage, difficulties in Indonesia and loss of markets in Germany, and lastly because of the rapid increase in population. These circumstances explain the relatively generous amount of Marshall Aid which, although at first sight it looks large, will on further consideration be seen to be in accordance with the real extent of the temporary economic difficulties of the country. At the same time it will be apparent that the Netherlands are faced with a problem of international adjustment which is necessarily more serious than the corresponding problem in other countries. For the Netherlands, therefore, the programme must concentrate even to a larger extent than elsewhere on the following points :

(I) An increase in exports relatively to pre-war conditions ;

(2) As a basis for this, a considerable increase in production, particularly in industrial production; hence

(3) Extensive new investment ;

(4) A moderate level of consumption; and

(5) Moderate levels of wages and prices.

1 Economisch-Statistisch Kwartaalbericht, Maart, 1948, p. 26. 
For the British reader who has been convinced by Mr. Harrod's pamphlet ${ }^{1}$ it may be stressed that the volume of investment necessary for the Netherlands, cannot but be much higher than the corresponding volume in Britain, particularly in view of the different population trend. The various reports so far published by the C.P.B. all emphasise the necessity for the programme contained in the above five points by trying to give them a numerical value.

Apart from the strict rationing of consumers' goods which is still enforced, and apart from the rigorous price and wage regulations still prevailing, the following suggestions have been made by the C.P.B. : (I) In order further to stimulate labour productivity, an extended application of piece-rates on the one hand, and of modern labour management methods on the other. (2) In order to stimulate industrialisation, further concessions in respect of the taxation of profits. Taxes on profits, which amounted to about 70 to 80 per cent during the war, have been reduced to 40 per cent; important tax concessions are also already available for new investment. In addition to these alleviations further industrial freedom seems to be called for in order to stimulate the process of readjustment. Accordingly, the C.P.B. considers that its future task lies especially in the field of employment policy. It is believed that within the framework of a good tax system and a well-advised employment policy (factors which partly overlap); and within the framework of existing international regulations (or those to be expected) the restoration of free enterprise would probably be all to the good. Experiments will probably be made in this respect through the industrial organisations which have lately been proposed. The activities of these bodies may either extend over rather a broad field or over only a restricted area, as seems most convenient after a process of trial and error. The preparation of a modern employment policy along these lines has already been begun. Apart from the tax proposals just mentioned, further proposals are now being investigated which would tend to concentrate the tax burden on boom years, and to create facilities for investment in depression periods. In addition a register of " reserve works," as they are called in Sweden, is being drawn up.

The Hague, Holland.

J. TINBERgen.

1 R. F. Harrod: Are these Hardships Necessary ? London, 1947. 